ISSN (Print) : :1412-7601

ISSN (Online) : 2654-8712

Volume 6, No.2 September 2020

EKONOBIS

http://www.ekonobis.unram.ac.id

\title{
Analisis Pengaruh Belanja Daerah Terhadap Pertumbuhan Product Domestic Regional Brutto (PDRB) Di Kabupaten Lombok Barat Tahun 2016-2019
}

\author{
Siti Fatimah, Yusuf Hasbullah.
}

Universitas Mataram

\section{ARTICLE INFO}

Keywords :

Regional Expenditure, GRDP Growth Rate, West Lombok Regency
ABSTRACT : The purpose of this study is to see the impact of regional spending on the growth of product domestic regional gross (PDRB) in West Lombok Regency 2016-2019. The hypothesis proposed is that regional expenditure has a relatively insignificant impact on the economic growth rate of West Lombok Regency 20162019. According to the level of explanation, this type of research is a descriptive study. Data collection techniques use library research and field research. The variables analyzed in this study include Direct Expenditures including: Reserve Fund formation consisting of: Regional Capital Participation, Regional Debt Principal Payments, and Regional Loans. Indirect Expenditures include: Personnel Expenditures, Interest Expenditures, Subsidized Spending, Grant Expenditures, Social Assistance Expenditures, Village Government Expenditures, Financial Assistance Expenditures to Kabupaen / City and Unexpected Expenditures. While the analysis model used is a). Analysis of regional expenditure growth on economic growth and b) Analysis of the contribution of regional spending to economic growth in West Lombok Regency 2016-2019. The results of the study show that the influence of regional spending on the growth of GRDP of West Lombok Regency tends to fluctuate in time series from 2016-2019. Furthermore, the results of this study can be taken into consideration by the West Lombok Regency Government in determining future policy recommendations.

Kata Kunci : Belanja Daerah, Laju Pertumbuhan PDRB, Kabupaten Lombok Barat

Corresponding Author:

Alamat : Program Studi Ekonomi Pembangunan, Fakultas Ekonomi dan Bisnis, Universitas Mataram, Jln. Majapahit No. 62 Mataram.

e-mail: sitifatimah@unram.ac.id

ABSTRAK: Tujuan penelitian ini adalah untuk melihat dampak belanja daerah terhadap pertumbuhan productdomestic regional brutto (PDRB) di kabupaten Lombok Barat Tahun 2016-2019. Hipotesis yang diajukan adalah Diduga bahwa belanja daerah mempunyai dampak terhadap laju pertumbuhan ekonomi Kabupaten Lombok Barat Tahun 2016-2019 yang relatif tidak terlalu significan. Menurut tingkat eksplanasinya jenis penelitian ini termasuk penelitian deskriptif. Teknik pengumpulan data menggunakan studi kepustakaan (Library Research) dan penelitian lapangan (Field Research). Variabel yang dianalisis dalam penelitian meluputi Belanja Langsung meliputi : Pembentukan Dana Cadangan yang terdiri dari : Penyertaan Modal Daerah, Pembayaran Pokok Utang Daerah, Pemberian Pinjaman Daerah. Belanja Tidak Langsung meliputi : Belanja Pegawai, Belanja Bunga, Belanja Subsidi, Belanja Hibah, Belanja Bantuan Sosial, Belanja Pemerintahan desa, Belanja Bantuan Keuangan Kepada Kabupaen/Kota dan Belanja Tidak Terduga. Sedangkan model analasis yang digunakan adalah a). Análisis pertumbuhan belanja daerah terhadap pertumbuhan ekonomi dan b) Analisis kontibusi belanja daerah terhadap pertumbuhan ekonomi di kabupaten Lombok Barat Tahun 2016-2019. Adapun hasil penelitian menunjukkan bahwa Pengaruh Belanja Daerah Terhadap Pertumbuhan PDRB Kabupaten Lombok Barat cendrung berfluktuatif secara time series terhitung sejak Tahun 2016-2019.Selanjutnya hasil penelitian inidapat dijadikan bahan pertimbangan oleh Pemerintah kabupaten lombok Barat dalam menentukan rekomendasi kebijakan dimasa yang akan datang. 


\section{PENDAHULUAN}

Latar Belakang

Penyelenggaraan pemerintah daerah sebagai sub sitem pemerintahan negara dimaksudkan untuk meningkatkan efektifitas dan efisiensi penyelenggaraan pemerintahan dan pelayanan masyarakat sesuai yang tertuang dalam Undangundang nomor : 25 Tahun 1999. Peranan dan kemampuan pemerintah daerah dalam pembangunan nasional diupayakan agar bertambah besar. Seiring dengan telah diberlakukannyaUndang-Undang Nomor : 32/2004 tentang Pemerintahan Daerah dan Undang-Undang Nomor : 33/2004 tentang Perimbangan Keuangan Antara Pemerintah Pusat dan Daerah, maka terhitung sejak itulah kewenangan pemerintah daerah semakin besar untuk mengatur rumah tangganya sendiri. Melalui otonomi daerah yang telah dituangkan dalam peraturan perundangundangan telah menimbulkan dampak yang cukup luas terhadap kewenangan pemerintah daerah termasuk perimbangan keuangan pusat dan daerah. Untuk penyusunan APBD memerlukan perhatian terutama dalam pendistribusian anggaran penerimaan pada sector-sektor yang dapat memacu pertumbuhan ekonomi secara berkesinambungan sebagaimana yang telah digariskan dalam pola dasar pembangunan daerah, Rencana pembangunan jangka menengah daerah (RPJMD) priode lima tahun. Sejalan dengan itu untuk melihat keberpihakan pola penyusunan anggaran Pendapatan dan Belanja Daerah yang secara eksplisit dapat dilihat melalui alokasi dana pembangunan daerah menjadai penting untuk dicermati secara lebih mendalam.

Distribusi anggaran belanja pembangunan melalui berbagai sector kegiatan secara proporsional dapat merupakan kebijakan yang ditempuh oleh pemerintah daerah dalam mendorong setor-sektor strategis guna meningkatkan pertumbuhan ekonomi yang selama ini masih didominasi oleh sector pertanian semata. Secara operasional semestinya alokasi dana-dana pembangunan memungkinkan untuk dapat mendorong sector ekonomi produktif sehingga secara multiplier dapat meningkatkan pendapaan daerah yang sekaligus meningkatkan pertumbuhan ekonomi daerah melalui peningkatan PDRB. Salah satu strategi yang dapat dilakukan disamping mendorong sector ekonomi produktif juga dapat memelui sector ekonomi dan sosial yang dapat mendatangkan sumber penerimaan baru untuk meningkatkan penerimaan daerah. 
Semua kegiatan di atas dapat dilakukan melalui realokasi sistem pengalokasin anggaran pembangunan, dimana paradigma penggunaan anggaran yang selama ini lebih banyak berbasis program atau proyek yang berbasis sosial dapat dialihkan ke program atau proyek yang berbasis ekonomi (value added). Untuk ituk sangat diperlukan análisis mengenai pengalokasian anggaran pembangunan, sehingga pencapaian sasaran pembangunan dapat lebih efisien dan efektif yang pada akhirnya dapat meningkat kesejahtraan masyarakat sebagai penerima manfaat dari pembangunan.

Kebijakan pemberian otonomi daerah merupakan langkah strategis dalam dua hal. Pertama, otonomi daerah dan desentralisasi merupakan jawaban atas permasalahan lokal bangsa Indonesia berupa ancaman disintegrasi bangsa, kemiskinan, ketidakmerataan pembangunan, rendahnya kualitas hidup masyarakat, dan masalah pembangunan sumber daya manusia. Kedua, otonomi daerah dan desentralisasi merupakan langkah strategis bangsa Indonesia untuk menyongsong era globalisasi ekonomi dengan memperkuat basis perekonomian daerah. (Mardiasmo, 2002:59).
Dari sisi reformasi keuangan sebagai pelaksanaan amanat otonomi, pemerintah telah menetapkan Peraturan Pemerintah Nomor 105 Tahun 2000 tentang Pengelolaan dan Pertanggungjawaban Keuangan Daerah yang mengatur mekanisme dan prosedur pengelolaan keuangan daerah yang transparan dan akuntabel berdasarkan asas kewajaran dan kepatutan. Dengan ditetapkannya Peraturan Pemerintah tersebut semakin membawa perubahan yang mendasar dalam pengelolaan anggaran daerah (APBD). Perubahan mendasar tersebut adalah adanya tuntutan akuntabilitas dan transparansi yang lebih besar dalam pengelolaan anggaran. Sebagaimana menurut Abdul Halim (2002:5) bahwa sebelum reformasi keuangan daerah, pertanggungjawaban atas pengelolaan anggaran daerah lebih ditujukan pada pemerintah yang lebih tinggi. Dengan adanya reformasi, pertanggungjawaban lebih ditujukan kepada rakyat melalui DPRD.

Terkait dengan fungsi dan tugas pemerintah daerah dalam era otonomi daerah akhir-akhir ini maka, tidak dapat dipungkiri lagi bahwa peranan identifikasi potensi dan sumber perolehan keuangan daerah menjadi sesuatu yang amat penting. Ini diharapkan akan mampu 
memberikan informasi yang lebih akurat mengenai alternatif sumber-sumber penerimaan daerah guna membiayai penyelenggaraan pemerintahan daerah. Secara implisit ketersediaan data mengenai perkembangan sumber-sumber penerimaan dan pengeluaran daerah dapat dijadikan bahan acuan pemerintah daerah dalam membuat perencanaan dan pola kebijakan pemerintah daerah terutama dalam pengelolaan keuangan daerah yang sekaligus dapat berfungsi sebagai bahan evaluasi sampai sejauhmana tingkat kemandirian dan desentralisasi fiskal daerah di era otonomi daerah sekarang ini. Mengingat APBD merupakan salah satu alat atau instrumen untuk meningkatkan pelayanan publik dan kesejahteraan masyarakat, maka dalam pelaksanaan otonomi daerah proses penyusunan dan pelaksanaan APBD harus sejalan dengan kepentingan dan kebutuhan publik atau masyarakat. Dalam kaitan dengan ini, APBD harus benar-benar dapat mencerminkan kebutuhan masyarakat dengan memperhatikan potensi dan keanekaragaman daerah.

Perumusan Masalah

1. Bagaimana Pengaruh Alokasi Belanja Daerah Terhadap Pertumbuhan Product Domestic
2. Regional Brutto (PDRB) di Kabupaten Lombok Barat Tahun 2014-2018

3. Seberapa besar kontribusi Alokasi Belanja Daerah Terhadap Pertumbuhan Product Domestic Regional Brutto (PDRB) di Kabupaten Lombok BaratTahun 2014-2018

\section{Tujuan Penelitian}

Adapun tujuan utama yang ingin diamati dalam penelitian ini adalah untuk :

1. Mengukur bagaimana Pengaruh Alokasi Belanja Daerah Terhadap Pertumbuhan Product Domestic Regional Brutto (PDRB) di Kabupaten Lombok Barat

Tahun 2014 - 2018

2. Mengukur seberapa besar kontribusiAlokasi Belanja Daerah Terhadap Pertumbuhan Product Domestic Regional Brutto (PDRB) di Kabupaten Lombok Barat Tahun 20142018

\section{Manfaat Penelitian}

1. Sebagai bahan evaluasi bagi Pemerintah Kabupaten Lombok Barat mengenai bagaimana perencanan anggaran belanja daerah agar dapat berdampak terhadap pertumbuhan ekonomi kabupaten Lombok Barat Tahun 2014-2018 sehingga dapat dirasakan oleh masyarakat. 
2. Sebagai bahan informasi untuk pengambilan kebijakan terutama dalam penentuan dan alokasi belanja daerah yang terkait dengan peningkatan pelayanan publik.

\section{KAJIAN PUSTAKA}

\section{Kinerja Keuangan Daerah}

Menurut Nizarwan dalam Halim (2004 : 70) dalam bukunya yang berjudul Bunga Rampai Manajemen Keuangan Daerah mengatakan Kebijakan umum pengelolaan keuangan daerah disesuaikan dengan situasi dan kondisi serta potensi daerah dengan berpedoman pada Undang-undang Nomor : 32 Tahun 2004 dan Undang-undang Nomor : 33 tahun 2004. Kesimpulannya adalah Kebijakan pengelolaan keuangan daerah dalam mengalokasikan belanja aparatur dan belanja pelayanan publik senantiasa berpegang pada prinsip anggaran berimbang dan dinamis serta efisien dan efektif dalam meningkatkan produktivitas Menurut Mardiasmo (2004) dalam bukunya yang berjudul Otonomi dan Manajemen Keuangan Daerah mengatakan Anggaran merupakan pernyataan mengenai estimasi kinerja yang hendak dicapai selama priode waktu tertentu yang dinyatakan dalamukuran finansial dan berisi rencana kegiatan yang direpresentasikan dalam bentuk rencana perolehan pendapatan dan belanja dalam satuan moneter.

Menurut Indra Bastian (2001 : 6) dalam bukunya yang berjudul Manual Akuntansi Keuangan Pemerintah Daerah mengatakan bahwa penyusunan APBD adalah suatu hal yang sangat penting dalam rangka penyelenggaraan fungsi daerah otonom yang bertujuan untuk : menentukan jumlah pajak yang akan dibebankan kepada masyarakat, suatu sarana untuk mewujudkan otonomi yang nyata dan bertanggung jawab, memberi isi dan arti dari pemerintah pusat ke pemerintah daerah, sarana untuk pengawasan dan pemberian kuasa kepala daerah untuk penyelenggaraan keuangan daerah.

Selanjutnya menurut Hasbullah (2006 : 4) Kinerja Keuangan Daerah merupakan suatu instrumen untuk mencermati kemampuan suatu daerah dalam aspek finansial untuk mengorganisir Anggararan Pendapatan dan Belanja Daerah (APBD) guna pencapaian visi dan misi pembangunan daerah guna peningkatan kesejahtraan masyarakat. Secara parsial dikatakan kinerja dapat diartikan sebagai alat ukur kemampuan suatu daerah dalam menggali unsur-unsur penerimaan baik 
penerimaan

aparatur

maupun

penerimaan publik dalam APBD (Anggaran

Pendapatan dan Belanja Daerah) untuk

selanjutnya dipergunakan sebagai belanja aparatur dan belanja publik sesuai dengan kebutuhan masyarakat.

\section{Pengelolaan Keuangan Daerah}

Dalam Peraturan Pemerintah Nomor 58 Tahun 2005 pengganti Peraturan Pemerintah Nomor 105 Tahun 2000 memberikan definisi Pengelolaan Keuangan Daerah adalah keseluruhan kegiatan yang meliputi perencanaan, pelaksanaan, penatausahaan, pelaporan, pertanggungjawaban, dan pengawasan keuangan daerah sedangkan Undangundang Nomor 17 Tahun 2003 tentang Keuangan Negara bahwa pendapatan daerah dan belanja daerah yang merupakan bagian dari keuangan negara harus dikelola secara tertib, taat pada peraturan perundang-undangan, efisien, ekonomis, efektif, transparan, dan bertanggungjawab dengan memperhatikan rasa keadilan dan kepatuhan.

Menurut Jaya dalam Munir, Djuanda, Tangkilisan (2004: 6) Keuangan Daerah adalah seluruh tatanan, perangkat kelembagaan dan kebijaksanaan anggaran daerah yang meliputi pendapatan dan belanja daerah, sedangkan menurut
Peraturan Pemerintah Nomor 105 Tahun 2000 menjelaskan Keuangan Daerah adalah semua hak dan kewajiban daerah dalam rangka penyelenggaraan pemerintahan daerah yang dapat dinilai dengan uang termasuk didalamnya segala bentuk kekayaan yang berhubungan dengan hak dan kewajiban daerah tersebut, dalam kerangka Anggaran Pendapatan dan Belanja Daerah (APBD).

Menurut Bastian (2001:8) adanya hubungan yang erat antara Keuangan Negara dan Keuangan Daerah yang merupakan dasar pengelolaan keuangan daerah. Sehingga baik dalam penyusunan APBD dan pelaporan keuangan daerah maupun pelaksanaannya, menceminkan pelaksanaan otonomi daerah yang nyata dan bertanggungjawab yang mencakup hal - hal sebagai berikut (1) Harus serasi dengan pembinaan politik dan kesatuan bangsa; (2) Harus dapat menjamin hubungan yang serasi antara pemerintah pusat dan pemerintah daerah atas dasar keutuhan negara kesatuan; (3) Harus dapat menjamin perkembangan dan pembangunan daerah termasuk prinsip prinsip pembagian sumber - sumber keuangan yang adil; (4) Mampu memberdayakan dan meningkatkan kemampua perekonomian daerah; (5) Dapat menciptakan sistem pembiayaan 
daerah yang adil, proporsional, rasional, transparan, partisipatif, bertanggungjawab (akuntabel) dan pasti; dan (6) Semakin mempertegassistem pertanggungjawaban keuangan oleh Pemerintah Daerah.

Menurut Devas et al dikutip dalam Munir, Djuanda, Tangkilisan (2004: 7) pengelolaan keuangan daerah berarti mengurus dan mengatur keuangan daerah itu sendiri berdasarkan pada prinsip-prinsip : (1) tanggung jawab, (2) mampu memenuhi kewajiban keuangan, (3) kejujuran, (4) hasil guna dan daya guna, dan (5) pengendalian. Melalui misi utama dan tujuan utama pengelolaan keuangan daerah di atas, terlihat bahwa pemerintah daerah harus mempertanggung jawabkan tugas keuangannya kepada lembaga atau orang yang berkepentingan yang sah, yang meliputi DPRD dan masyarakat. Selain itu efektivitas dan efisiensi dalam pengelolaan keuangan daerah juga harus dilaksanakan. Hal ini berarti dalam pengelolaan keuangan daerah harus dilaksanakan sedemikian rupa sehingga program dan kegiatan yang telah direncanakan dapat dilaksanakan untuk mencapai tujuan pemerintah daerah dengan biaya yang serendah-rendahnya dan dalam waktu yang secepat-cepatnya. Secara garis besar, manajemen keuangan daerah dapat dibagi menjadi dua bagian, yaitu manajemen penerimaan daerah dan manajemen pengeluaran daerah. Kedua komponen tersebut akan sangat menentukan kedudukan suatu pemerintah daerah dalam rangka melaksanakan otonomi daerah (Mardiasmo, 2002).

$$
\text { Selanjutnya Nizarwan }
$$

mengatakan kebijakan umum pengelolaan keuangan daerah hendaknya harus memperhatikan berbagai hal seperti : (1) Dalam mengalokasikan anggaran baik rutin maupun pembangunan senantiasa berpegang pada prinsip-prinsip anggaran berimbang dan dinamis serta efisien dan efektif dalam meningkatkan produktivitas; (2) Anggaran rutin diarahkan untuk menunjang kelancaran tugas pemerintahan dan pembangunan; (3) Anggaran pembangunan diarahkan untuk meningkatkan sektor-sektor secara berkesinambungan dalam mendukung penyempurnaan maupun memperbaiki sarana dan prasarana yang dapat menunjang peningkatan pembangunan dan kemasyarakatan dengan memperhatikan skala prioritas.

\section{Anggaran Pendapatan dan Belanja Daerah (APBD)}

Menurut UU Nomor 32 Tahun 2004 tentang Pemerintahan Daerahsumber 
penerimaan daerah terdiri dari (1)

Pendapatan Asli Daerah (PAD),(2) Dana

Perimbangandan (3) Lain-lain pendapatan daerah yang syah. Sedangkan menurut UU Nomor 33 Tahun 2004 tentang Perimbangan Keuangan Antara Pemerintah Pusat dan Pemerintah Daerah dalam pasal 5 ayat (1) menyatakan bahwa penerimaan daerah dalam pelaksanaan desentralisasi terdiri atas pendapatan daerah dan pembiayaan. Selanjutnya ayat 2 menjelaskan bahwa pendapatan daerah sebagaimana dimaksud pada ayat 1 bersumber dari : (1) Pendapatan Asli Daerah (PAD), (2) Dana Perimbangan dan (3) Lain-lain pendapatan.

Menurut Surat Edaran Menteri Dalam Negeri RI Nomor 903/2477/SJ tanggal 5 Desember 2001 perihal Pedoman Umum Penyusunan dan Pelaksanaan APBD Tahun Anggaran 2002, bahwa penyusunan APBD harus mengacu pada norma dan prinsip anggaran sebagai berikut:

\section{Transparansi dan Akuntabilitas Anggaran}

Merupakan persyaratan utama untuk mewujudkan pemerintahan yang baik, bersih dan bertanggungjawab. Sebagai instrument evaluasi pencapaian kinerja dan tanggungjawab Pemerintah Daerah mensejahterakan masyarakat, maka APBD harus dapat menyajikan informasi yang jelas tentang tujuan, sasaran, hasil dan manfaat yang diperoleh masyarakat dari suatu kegiatan atau proyek yang dianggarkan yang meliputi :

a. Disiplin Anggaran

APBD harus disusun berorientasi pada kebutuhan masyarakat tanpa harus meninggalkan keseimbangan antara pembiayaan penyelenggaraan pemerintahan, pembangunan dan pelayanan masyarakat. Oleh karena itu penyusunan anggaran hendaknya dilakukan berlandaskan azas efisiensi, tepat guna, tepat waktu pelaksanaan dan penggunaannya dapat dipertanggungjawabkan.

b. Keadilan Anggaran

Pendapatan Daerah pada hakekatnya diperoleh melalui mekanisme pajak dan retribusi atau beban lainnya yang dipikul oleh segenap lapisan masyarakat. Untuk itu, Pemerintah Daerah wajib mengalokasikan pengunaannya secara adil dan merata agar dapat dinikmati oleh seluruh kelompok masyarakat tanpa diskriminasi dalam pemberian pelayanan.

Menurut Mardiasmo

(2004) anggaranmerupakan pernyataan mengenai estimasi kinerja yang hendak dicapai selama periode waktu tertentu yang dinyatakan dalam ukuran finansial dan berisi rencana kegiatan yang 
direpresentasikan dalam bentuk rencana perolehan pendapatan dan belanja dalam satuan moneter. Anggaran sektor publik merupakan instrumen akuntabilitas atas pengelolaan dana publik dan pelaksanaan program - program yang dibiayai dengan uang publik. Penganggaran sektor publik terkait dengan proses penentuan jumlah alokasi dana untuk tiap - tiap program dan aktifitas dalam satuan moneter.

\section{Belanja Daerah}

Setiap kepala daerah dalam Sistem perencanaan belanja daerah merupakan bentuk implementasi pencapaian visi, misi dan program seorang kepala daerah sesuai yang pernah disampaikan dalam kampanye, sehingga secara faktual alokasi anggaran tidak saja dialokasikan untuk belanja rutin semata, namun lebih banyak dialokasikan untuk belanja pembangunan. Karena melalui kegiatan belanja pembangunan akan dapat dilihat sejauhmana seorang kepala daerah itu berkomitmen dalam orientasi pelayanan publik.

\section{Perhitungan Anggaran}

Mengingat APBD merupakan salah satu alternatif yang dapat merangsang kesinambungan serta konsistensi pembangunan di daerah, maka model penyusunan perhitungan APBD akan sangat erat kaitannya dengan keberhasilan pelaksanaan anggaran. Untuk itu sistem, prosedur, format dan struktur APBD yang selama ini digunakan, sangat tidak mampu mendukung tuntutan perubahan, dengan demikian perlu suatu perencanaan APBD yang lebih sistematis, terstruktur dan komprehensif (Mardiasmo, 2001: 5).

\section{METODE PENELITIAN}

\section{Jenis Penelitian}

Penelitian ini termasuk penelitian deskriptif karena lebih menampilkan dokumen dan data-data faktual. Penelitian deskriptif adalah penelitian yang dilakukan untuk mengetahui nilai variabel mandiri, baik satu variabel atau lebih (independent) tanpa membuat perbandingan atau menghubungkan dengan variabel yang lain (Sugiyono, 1999:11). Selanjutnya menurut Kuncoro (2003:8) Penelitian deskriptif meliputi pengumpulan data untuk diuji hipotesis atau menjawab pertanyaan mengenai status terakhir dari subjek penelitian. Penelitian deskriptif berupaya untuk memperoleh deskripsi yang lengkap dan akurat dari suatu situasi.

\section{Lokasi Penelitian}

Penelitian ini dilaksanakan di Kabupaten Lombok Barat Provinsi Nusa Tenggara Barat, dipilihnya Kabupaten Lombok Barat 
secara purposive sampling dengan dasar pertimbangan bahwa Kabupaten Lombok Barat merupakan kabupaten yang cukup tinggi angka pertumbuhan PDRB-nya di Provinsi Nusa Tenggara Barat. Berdasarkan kenyataan tersebut peneliti ingin melihat lebih jauh tingginya pertumbuhan PDRB tersebut semata disebabkan oleh variabel tertentu ataukah hal-hal lain diluar model. Diharapkan dengan terpilihnya Kabupaten Lombok Barat sebagai lokasi penelitian akan memberikan berbagai kemudahan dari berbagai akses seperti data dan informasi lainnya.

\section{Teknik dan Alat Pengumpulan Data}

Data dan informasi yang berkaitan dengan alokasi dana pembangunan dan alokasi dana rutin di Kabupaten Lombok Barat dilakukan dengan cara :

a. Studi kepustakaan (Library Research), yaitu dengan cara mempelajari buku-buku, karangan ilmiah, jurnal ilmiah serta dokumen-dokumen lain yang berkaitan dengan belanja daerah seperti yang dituangkan dala halhal yang akan dianalisis di atas.

b. Penelitian lapangan (Field Research), yaitu melakukan pengamatan secara langsung di lapangan terutama pada Biro
Keuangan Sekretariat Daerah Kabupaten Lombok Barat Provinsi NTB sehubungan dengan datadata dan informasi terkait dengan variabel-variabel penelitian dan hal-hal yang akan dianalisis di atas.

\section{Jenis dan Sumber Data}

Penelitian ini menggunakan data primer yaitu data yang dikumpulkan langsung dari Biro sekretariat Daerah Kabupaten Lombok Barat sesuai data yang diperlukan dalam penelitian. Adapun data primer yang dimaksudkan terdiri dari : data APBD, Perubahan APBD, belanja daerah, alokasi dana pembangunan, alokasi dana rutin, pertumbuhan PDRB selama lima Tahun kabupaten Lombok Barat Provinsi NTB Tahun Anggaran 2014-2018.

Sedangkan data sekunder yang digunakan merupakan data yang sudah dikumpulkan dan dipublikasikan kepada masyarakat pengguna data serta data yang diperoleh melalui pihak kedua atau secara tidak langsung. Adapun data skunder yang dimaksudkan terdiri dari : data alokasi dana pembangunan, alokasi dana rutin, perkembangan PDRB, data demografis, perkembangan APBD, lainnya yang mendukung judul penelitian.

\section{Identifikasi dan Klasifikasi Variabel}

Dalam penelitian ini variabel yang diidentifikasi adalah sebagai berikut: 
a. Belanja Langsung meliputi :

Pembentukan

Dana

Cadangan,Penyertaan

Modal daerah,Pembayaran

Pokok

Utang

Daerah,Pemberian

pinjaman daerah

b. Belanja Tidak Langsung

meliputi : Belanja Pegawai,

Belanja Bunga, Belanja

Subsidi, Belanja Hibah,

Belanja Bantuan Sosial,

Belanja Pemerintahan

desa, Belanja bantuan

Keuangan Kepada

Kabupaen/Kota, Belanja

Tidak Terduga, Product

Domestic Regional Brutto (PDRB)

\section{Definisi Operasional Variabel}

Untuk menghindari penafsiran yang berbeda terhadap beberapa variabel yang digunakan dalam penelitian ini maka diberikan batasan-batasan sebagai berikut 1.Belanja Langsung meliputi :

a. Pembentukan Dana Cadangan adalah dana yang dicadangkan dalam alokasi Anggaran Pendapatan dan Belanja Negara (APBD) untuk hal-hal yang bersifat tidak terduga. b. Penyertaan Modal Daerah merupakan bentuk komitmen pemerintah daerah dalam mengalokasikan sejumlah anggaran dalam APBD guna mendorong laju pertumbuhan ekonomi daerah.

c. Pembayaran Pokok Utang Daerah merupakan suatu kewajiban setiap pemerintah daerah yang telah melakukan akad pinjam meminjam dengan pihak ketiga dan harus tetap dianggarkan melalui APBD setiap tahun.

d. Pemberian pinjaman daerah merupakan surplus dana anggaran yang diperoleh dari sumber penerimaan daerah dan untuk siap diperpinjamkan kepada pihak ketiga dengan perjanjian tertentu.

2. Belanja Tidak Langsung meliputi :

a. Belanja Pegawai merupakan kewajiban pemerintah daerah untuk menganggarkan sejumlah dana tertentu melalui APBD guna membayar gaji pegawai yang menjadi tanggungan daearah sesuai jumlah pegawai yang ada.

b. Belanja Bunga merupakaan sejumlah kewajiban pemerintah daerah akibat dari sejumlah 
pinjaman nilai utang tertentu sesuai perjanjian.

c. Belanja Subsidi merupakan pengeluaran yang dikeluarkan oleh pemerintah daerah untuk kepentingan/bantuan/subsidi daerah yang mengalami kekurangan/defisit anggaran belanja daerah.

d. Belanja Hibah merupakan suatu bentuk bantuan yang dialokasikan pemerintah daerah untuk tujuan dan kepentingan-kepentingan membantu masyarakat yang memerlukan.

e. Belanja Bantuan Sosial merupakan suatu bentuk kewajiban moral pemerintah daerah untuk mengalokasikan sejumlah dana tertentu guna ditujukan untuk kepentingan sosial.

f. Belanja Pemerintahan Desa merupakan dana anggaran desa yang dialokasikan melalui APBN guna percepatan pembangunan di daerah pedesaan.

g. Belanja bantuan Keuangan Kepada Kabupaen/Kota merupakan bantuan dana yang bersumber dari dana alokasi umum dan dana alokasi khusus yang diberikan kepada daerah yang mengalami defisit anggaran guna pelaksanaan pembangunan.

h. Belanja Tidak Terduga merupakan sejumalh dana yang dialokasikan oleh pemerintah daerah guna mengantisipasi kejadian-kejadian yang bersifat tidak terduga terutama yang disebabkan oleh gangguan alam.

i. Perkembangan PDRB adalah jumlah PDRB yang diterima setiap tahun oleh pemerintah kabupaten Lombok Barat terhitung sejak Tahun 2014-2018.

\section{Model Analisis Data}

a. Analisis Belanja Daerah dan Laju Pertumbuhan Terhadap PDRB Guna mendapatkan gambaran tentang pengaruh belanja daerah terhadap laju pertumbuhan PDRB dan kontribusinya selama lima tahun terakhir (2014-2018) akan dianalisis dengan formulasi Widodo dalam Muin (2003: 36) yang disesuaikan sebagai berikut :

dimana :

$\Delta \mathrm{Xt}=$ Pertumbuhan Belanja Daerah Xt = Laju Pertumbuhan Belanja Daerah $\mathrm{X} 1 \mathrm{t}=$ Laju Pertumbuhan PDRB.

b. Analisis Kontribusi Belanja Daerah Terhadap Laju Pertumbuhan PDRB Untuk menghitung besarnya kontribusi anggran belanja daerah setiap tahunnya 
terhadap laju pertumbuhan ekonomi kabupaten Lombok Barat Tahun 20142018 dengan rumus :

$$
P=\frac{\sum A S}{\sum A P} \times 100 \%
$$

dimana :

$\mathrm{P} \quad=$ kontribusi belanja daerah

AS = jumlah belanja daerah tahun- $\mathrm{t}$

$\mathrm{AP} \quad=$ jumlah PDRB tahun $-\mathrm{t}$

\section{HASIL DAN PEMBAHASAN}

\section{Kondisi Demografis}

Pertumbuhan penduduk akan selalu dikaitkan dengan tingkat kemiskinan, kematian dan perpindahan penduduk atau migrasi baik perpindahan ke luar maupun dari luar. Pertumbuhan penduduk adalah peningkatan atau penurunan jumlah penduduk suatu

Tabel 1. Jumlah Penduduk Kabupaten Lombok Barat Dirinci Menurut Jenis Kelamin Tahun 2016-2019.(ribuan)

\begin{tabular}{|l|l|l|l|l|l|}
\hline Penduduk & \multicolumn{5}{|c|}{ Tahun } \\
\hline & 2014 & 2015 & 2016 & 2017 & 2018 \\
\hline Laki-laki & 315.094 & 320.102 & 325.213 & 335.111 & 345.145 \\
\hline Perempuan & 329.492 & 334.790 & 339.919 & 345.040 & 355.244 \\
\hline Jumlah & 644.586 & 654.892 & 665.132 & 675.222 & 700,389 \\
\hline Laju Pertumbuhan & 2,00 & 2,00 & 2,00 & 1,52 & 1,49 \\
\hline
\end{tabular}

Sumber : BPS Kabupaten Lombok Barat Tahun 2016-2019

Memperhatikan jumlah penduduk pada table 1, maka dapat dikatakan bahwa pada tahun 2014 jumlah penduduk di Kabupaten Lombok Barat hanya mengalami sedikit peningkatan yaitu daerah dari waktu ke waktu. Pertumbuhan penduduk yang minus berarti jumlah penduduk yang ada pada suatu daerah mengalami penurunannyang bias disebabkan oleh berbagai kondisi. Pertumbuhan penduduk meningkat jika jumlah kelahiran dan perpindahan penduduk dari luar ke dalam lebih besar dari jumlah kematian dan perpindahan penduduk dari dalam ke luar. Jumlah penduduk di Kabupaten Lombok Barat dari tahun ketahun terus meningkat. Berdasarkan data dari Badan Pusat Statistik Kabupaten Lombok Barat sampai dengan tahun 2014 data jumlah penduduk diKabupaten Lombok Barat telah mencapai 644.586 jiwa yang terdiri dari laki-laki sekitar 315.094 Jiwa dan perempuan 329.492 jiwa. 
2,00 persen per tahun terus mengalami penurunan menjadi 1,52 persen tahun 2017 dan 1,49 persen di tahun 2018.

\section{Perkembangan Indikator Agregat Lombok Barat}

Secara umum, pencapaian target indikator agregat Kabupaten lombok Barat cukup bervariasi. Dalam RPJMD Priode 2013-2017, pemerintah Kabupaten Lombok Barat telah menetapkan ada 8 (delapan) indikator agregat untuk mengukur kinerja pembangunan. Kedelapan indikator kinerja itu adalah : laju Pertumbuhan Ekonomi (LPE),Tingkat Kemiskinan (TK),Indeks Pembangunan Manusia (IPM),Tingkat Pengangguran Terbuka (TPT), Nilai Tukar Petani (NTP), Indeks Gini (IG), Indeks Inflasi dan (II), Indeks Pembangunan Gender (IPG)

Dari delapan indikator yang ditetapkan dalam RPJMD Tahun 20132017 yang diamati dalam penelitian ini, belanja daerah yang dikaitkan dengan laju pertumbuhan ekonomi daerah (PDRB) dimana pertumbuhan ekonomi merupakan satu-satunya indikator yang mengalami pertumbuhan yang cukup signifikan bahkan mampu melalui target RPJMD. Sementara itu tujuh indikator lainnya menunujukkan perkembangan yang cukup bervariatif : Dimana tingkat kemiskinan dan indeks pemangunan manusia menunjukkan perbaikan namun belum mencapai target yang ditetapkan dalam RPJMD. Tingkat pengangguran terbuka walaupun masih dapat dipertahankan di bawah rata-rata nasional namun mengalami sedikit peningkatan pada tahun 2016 sehingga semakin menjauh dari target RPJMD. Sementara itu indeks nilai tukar petani rata-rata perbulan mengalami penurunan pada priode tahun 2015-2017.

\section{Perekonomian}

Pada tahun 2014 dan 2015 prekonomian Kabupaten Lombok Barat mengalami pertumbuhan yang sangat berarti. Namun pada tahun 2016 mengalami penurunan sebesar 2,32 persen dari tahun sebelumnya yaitu 2015, namun pada tahun berikutnya mengalami pertumbuhan 0,33 pada tahun 2017 dan 3,00 persen pada tahun 2018. Selain merupakan angka pertumbuhan riil cukup tinggi, angka tersebut telah mampu menempatkan Kabupaten Lombok Barat sebagai kabupaten tertinggi kedua di Kabupaten Lombok Barat, walaupun secara konkrit belum melampaui target RPJMD. Kendatipun angka pertumbuhan prekonomian kabupaten Lombok Barat belum melampaui target RPJMD namun jika diamati pendapatan per kapita sudah 
mendekati pendapatan rata-rata secara nasional.

Selain kenaikan pendapatan ratarata banyak disumbang oleh pertumbuhan ekonomi diluar sub-sektor pertambangan, non migas. Pertumbuhan yang cukup tinggi pekonomian kabupaten Lombok Barat tahun 2014-2015 dan tahun 2017-2018. Jika dilihat secara agregat pertumbuhan dimaksud banyak disumbang oleh Sektor Industri pengolahan dan Sektor Jasa perbankan. Sebagai salah satu kontributor terbesar prekonomian kabupaten Lombok Barat Sektor industri pengolahan mengalami pertumbuhan yang cukup signifikan karena dukungan yang cukup kuat dari aspek jasa perbankan dalam mengakses permodalan. Ini telah banyak memberikan dampak terhadap kemajuan Sektor industri pengolahan di Kabupaten Lombok Barat.

Laju pertumbuhan Sektor pertanian kian lama kian menurun dari tahun sebelumnya. Dalam dekade dua tahun terakhir 2014 dan 2015 dan tahun 20172018 sumbangan Sektor pertanian terhadap pembentukan PDRB kabupaten Lombok barat nampaknya kian mengalami penurunan walaupun tidak terlalu significan. Jika diamati secara agregat peningkatan prekonomian kabupaten
Lombok Barat tidak lagi harus bertumpu pada Sektor pertanian semata, namun ditunjang oleh sector industry pengolahan. Sekaligus perlu dilakukan diversifikasi pangan dan ekstensifikasi lahan secara berkesinambungan.

\section{Ketenagakerjaan}

Meskipun tingkat pengangguan masih relatif rendah, sebagian besar tenaga kerja di kabupaten Lombok Barat di Sektor informal. Dalam lima tahun terakhir terhitung sejak tahun 2014, 2015, 2016, 2017 dan 2018 tingkat pengangguran terbuka kabupaten Lombok Barat selalu berada lebih rendah dari ratarata tingkat pengangguran secara Nasioal. Namun demikian berdasarkan data tahun 2016 dan data tahun 2017 lebih dari 75 persen tenaga kerja kabupaten Lombok Barat masih bekerja pada Sektor informal. Di Sektor pertanian misalnya dengan daya serap sekitar empat puluh lima persen masih bekerja pada Sektor informal. Sektor industri pengolahan dan Jasa kendatipun merupakan kontributor terbesar terhadap pertumbuhan ekonomi namun hanya mampu menyerap sekitar 3,5 persen pekerja dan hanya 43 persen diantaranya yang bekerja di Sektor formal. Di Sektor lainnya lebih dari setengahnya merupakan pekerja di Sektor informal. Selain didominasi oleh pekerja Sektor 
informal rendahnya tingkat pengangguran di kabupaten Lombok Barat juga sangat dipengaruhi oleh tingginya pekerja migran terutama tenaga kerja migran keluar negeri seperti ke Malaisia dan Timur Tengah.

\section{Kemiskinan}

Kemiskinan masih merupakan tantangan besar kabupaten Lombok Barat, meskipun tingkat kemiskinan sudah berhasil diturunkan dari 28,00 persen tahun 2014 menjadi 23,00 persen di tahun 2015. Apalagi jika dilihat berdasarkan angka kemiskinan Kabupaten Lombok Barat, kita masih termasuk Kabupaten yang tingkat kemiskinannya tertinggi di Indonesia. Selain itu juga angka kesenjangan kemiskinan yang masih tergolong cukup lebar/tinggi. Kesenjangan ini juga masih juga tergolong tinggi jika dibandingkan dengan target yang ditetapakan dalam RPJMD Tahun 20132017. Kondisi ini menggambarkan betapa kerja keras pemerintah kabupaten Lombok Barat merupakan sebuah keharusan untuk bisa mencapai targettarget yang ditetapkan dalam RPJMD bahkan untuk tahun-tahun selanjutnya.

Jika dilihat dari kacamata spasial (kedaerahan), ternyata tingkat kemiskinan pedesaan jauh lebih cepat penurunannya jika dibandingkan dengan perkotaan. Ini diindikasikan oleh semakin banyaknya angkatan kerja di daerah pedesaan yang melakukan migrasi keluar negeri utamanya sebagai Tenaga Kerja Indonesia (TKI) dan meningkatnya jumlah Remitansi atau arus pemgiriman uang yang berasal dari tenaga kerja Indonesia yang berada di luar negeri. Kondisi ini telah menimbulkan multiplier effek terutama di daerah asal tenaga kerja dan mempercepat penurunan angka kemiskinan terutama daerah asal pengirim tenaga kerja tersebut. Termasuk telah membawa efek terhadap tingkat kedalaman kemiskinan dan tingkat keparahan kemiskinan yang ada di desa asal pengiriman tenaga kerja Indonesia (TKI).

\section{Indeks Pembangunan Manusia}

Sejak tahun 2017-2018 angka Indeks Pembanguna Manusia (IPM) di kabupaten Lombok Barat telah mengalami peningkatan. Peningkatan ini memang relatif sangat kecil. Pada tahun 2017 misalnya angka Indek Pembangunan Manusianya sebesar 67,2 persen menjadi 67,7 persen di tahun 2018. Rendahnya peningkatan Indek Pembangunan Manusia ini lebih disebabkan oleh masih rendahnya indikator pendidikan (rata-rata lama sekolah dan angka melek huruf) serta indikator kesehatan (angka harapan hidup). Sebagai akibat dari kecilnya angka 
kenaikan angka Indeks Pembangunan Manusia (IPM) ini sehingga target yang selama ini direncanakan dalam RPJMD Tahun 2013-2017 belum dapat dicapai. Sebagai konsekuaensi dari ditetapkannya target RPJMD bidang peningkatan Indeks Pembanguna Manusia membawa konsekuensi terhadap perlu adanya percepatan eksekusi program dan kegiatan teruatama bidang pendidikan, kesehatan dan infra struktur pendukung lainnya.

\section{Pendapatan}

1.Gambaran Umum Pendapatan Lombok Barat

Pendapatan pemerintah kabupaten Lombok Barat secara time series terus mengalami peningkatan secara significan baik secara nominal maupun secara riil.
Dalam lima tahun terakhir pertumbuhan pendapatan kabupaten Lombok Barat meningkat secara signifikan. Peningkatan ini tidak saja disebabkan oleh kenaikan pendapatan asli daerah (PAD), juga disebabkan oleh terjadinya kenaikan alokasi dana perimbangan dari pusat baik untuk dana Alokasi Umum (DAU) mapun Dana Alokasi Khusus (DAK), termasuk terjadinya peningkatan dari sumbersumber penerimaan lain yang syah seperti : kenaikan deviden yang disetorkan ke Kas Daerah yang bersumber dari hasil penyertaan modal pada BUMD-BUMD yang ada di kabupaten Lombok Barat. Untuk lebih jelasnya gambaran penerimaan daerah Kabupaten Lombok Barat selama 5 (lima) tahun dapat disajikan pada tabel di bawah ini.

Tabel 2. Pendapatan Daerah Kabupaten Lombok Barat Sejak Tahun 2016-2019

\begin{tabular}{|c|c|c|c|}
\hline No. & Tahun & Pendapatan Daerah (Rp) & Pertumbuhan (\%) \\
\hline 1 & 2014 & $1.142 .644 .084 .627,59$ & 12,00 \\
\hline 2 & 2015 & $1.280 .761 .936 .263,42$ & 15,00 \\
\hline 3 & 2016 & $1.473 .782 .176 .795,89$ & 9,00 \\
\hline 4 & 2017 & $1.603 .198 .969 .453,92$ & 9,00 \\
\hline 5 & 2018 & $1.747 .302 .315 .012,00$ & 10,20 \\
\hline & Jumlah & & 55,20 \\
\hline & Rata-rata & & 11,04 \\
\hline
\end{tabular}

Sumber : BPS Kabupaten Lombok Barat Tahun 2016-2019

Berdasarkan data tabel 2 di atas bahwa pendapatan daerah mulai tahun 2014-2018 berfluktuasi, sebagai contoh tahun 2015 terjadi peningkatan pendapatan ycukup signifikan yaitu sebesar 15,00 persen dari tahun 2014. Namun pada tahun 2016 dan 2017 terjadi penurunan menjadi 9, 00 persen. Kendatipun pada tahun 2018 terjadi kenaikan menjadi 10,20 persen. Ini 
mengindikasikan adanya fluktuasi yang cendrung disebabkan oleh terjadinya penurunan alokasi dana perimbangan yang bersumber dari dana Alokasi Umum (DAU) dan Dana Alokasi Khusus (DAK) disamping in-efisiensi dalam pemungutan pendapatan daerah yang bersumber dari berbagai bidang seperti Pendapatan Asli Daerah (PAD), Dana Perimbangan (DAU dan DAK) serta lain-lain pendapatan yang syah. Dilihat dari segi rata-rata laju pertumbuhan pendapatan daerah selama 5 (lima) tahun terakhir telah terjadi peningkatan sebesar 11,04 persen tiap tahun.

\section{Pendapatan Asli Daerah Lombok Barat}

Kapasitas perolehan Pendapatan asli daerah (PAD) kabupaten Lombok Barat sudah semakin setara dengan pemerintah Kabupaten secara nasional, namun PAD per Kapita pemerintah kabupaten Lombok Barat masih kecil. Pada tahun 2014 perolehan PAD kabupaten Lombok Barat diperkirakan sebesar 5,23 persen dari PDRB. Angka ini sedikit diatas kapasitas rata-rata pemerintah provinsi dan secara nasional yang baru mencapai 1,07 persen. Pada tahun 2014, kontribusi bagian laba usaha daerah mengalami peningkatan yang cukup significan. Sampai tahun 2014 sumber utama PAD pemerintah kabupaten Lombok Barat berasal dari penerimaan pajak daerah dengan kontribusi rata-rata per tahun pada priode 2014-2018 sebesar 74,2 persen, disusul oleh sumber retrebusi daerah dengan rata-rata kontribusi sebesar 10,2 persen. Pada tahun 2017 peningkatan sumber bagian laba usaha ndaerah dari rata-rata sebesar 5 persen ( 2014-2018) menjadi 15,5 persen. Angka ini jauh lebih besar dari pendapatan retrebusi daerah pada tahun yang sama yang hanya sebesar 9,8 persen. Peningkatan kontribusi sumber bagian laba usaha daerah ini menandai telah terjadinya diversifikasi PAD kabupaten Lombok Barat dari pajak dan retrebusi yang selama ini menjadi pendapatan dominan.

Dalam hal melihat bagaimana kemampuan tingkat PAD di Kabupaten Lombok Barat selama lima tahun terakhir (2014-2018) dapat dilakukan dengan cara membandingkan besarnya PAD dengan pertumbuhan PDRB dan jumlah Kecamatan se Kabupaten Lombok Barat. Adapun hasil selengkapnya dapat diperhatikan pada tabel di bawah ini. 
Tabel 3. Tingkat PAD Pemerintah Kabupaten Lombok Barat Tahun 2016- 2019. (dalam ribuan rupiah)

\begin{tabular}{|c|c|c|c|c|c|}
\hline No. & $\begin{array}{c}\text { Tahun } \\
\text { Anggaran }\end{array}$ & PAD & $\begin{array}{c}\text { Dana } \\
\text { Perimbangan }\end{array}$ & $\begin{array}{c}\text { Lain-lain } \\
\text { Pendapatan Yg } \\
\text { Syah }\end{array}$ & $\begin{array}{c}\text { Jumlah } \\
\text { (Rp) }\end{array}$ \\
\hline 1 & 2014 & 176.452 .185 & 764.534 .231 & 235.312 .541 & 1.176 .298 .957 \\
\hline 2 & 2015 & 182.437 .273 & 851.176 .897 & 247.147 .764 & 1.280 .761 .934 \\
\hline 3 & 2016 & 238.730 .142 & 1.120 .665 .666 & 243.803 .160 & 1.603 .198 .968 \\
\hline 4 & 2017 & 290.993 .583 & 1.367 .400 .034 & 241.170 .721 & 1.699 .564 .338 \\
\hline 5 & 2018 & 301.153 .695 & 1.112 .197 .596 & 333.951 .023 & 1.747 .302 .314 \\
\hline & Jumlah & 1.189 .766 .878 & 5.215 .974 .424 & 1.301 .385 .209 & 7.507 .126 .511 \\
\hline & Rata-rata & 237.953 .375 & 1.043 .194 .884 & 260.277 .041 & 1.501 .425 .302 \\
\hline
\end{tabular}

Sumber : Kabupaten Lombok Barat Tahun 2016-2019

Variasi nilai tingkat PAD menunjukkan fluktuasi yang relatif rendah atau kecil, ini secara faktual mengindikasikan betapa besarnya penerimaan daerah yang bersumber dari pendapatan asli daerah peningkatannya juga masih kecil. Selanjutnya pertumbuhan ekonomi yang ditunjukkan dengan pertumbuhan PDRB juga mengalami peningkatan yang relatif tidak terlalu besar. Sehingga secara teori pemerintah Kabupaten Lombok Barat harus meningkatkan nilai PAD-nya minimal 1,53 kali jumlah PAD yang diterima sekarang, baru tingkat PAD yang ideal dapat terpenuhi.

\section{Belanja Daerah}

Selanjutnya jika kita perhatikan dari sisi pertumbuhan belanja, maka kondisi belanja daerah Kabupaten Lombok Barat sejak Tahun 2014-2018 dapat dilihat pada tabel berikut :

Tabel 4. Belanja Daerah Kabupaten Lombok Barat Sejak Tahun 2016-2019.

\begin{tabular}{|c|c|c|c|}
\hline No. & Tahun & Belanja Daerah (Rp) & Pertumbuhan (\%) \\
\hline 1 & 2014 & $1.115 .213 .561 .837,76$ & 25,00 \\
\hline 2 & 2015 & $1.390 .491 .598 .626,42$ & 7,00 \\
\hline 3 & 2016 & $1.484 .537 .233 .745,94$ & 13,00 \\
\hline 4 & 2017 & $1.668 .418 .316 .826,90$ & 9,00 \\
\hline 5 & 2018 & $1.730 .565 .286 .739,00$ & 4,20 \\
\hline & Jumlah & $7.389 .225 .994 .561,00$ & 58,20 \\
\hline & Rata-rata & $1.477 .845 .198,805,00$ & 11,64 \\
\hline
\end{tabular}

Sumber : BPS Kabupaten Lombok Barat Tahun 2016-2019

Bersadarkan data tabel di atas bahwa belanja daerah mulai tahun 2014-2018 berfluktuasi juga, sebagai contoh tahun
2014 terjadi peningkatan belanja daerah yang sangat signifikan yaitu sebesar 25,00 persen dari tahun 2013. Namun pada 
tahun 2015terjadi penurunan menjadi 7,00 persen dari Tahun 2014. Namun pada Tahun 2016 terjadi peningkatan lagi secara signifikan menjadi 13,00 persen dari tahun 2015. Namun pada Tahun 2017 dan 2018 terjadi penurunan belanja daerah secara signifikan menjadi 9,00 persen dan 4,20 persen. Fluktuasi ini mengindikasikan adanya efisiensi belanja daerah baik untuk belanja langsung maupun belanja tidak langsung, sehingga untuk tahun 2018 terjadi surplus anggaran sebesar Rp 16.646.028.273,-- Dilihat dari segi rata-rata laju pertumbuhan belanja daerah selama 5 (lima) tahun sebesar 11,64 persen tiap tahun.

Adapun komponen belanja daerah ini meliputi belanja langsung yang terdiri dari : belanja pegawai, belanja barang dan jasa, penyertaan modal dan pembayaran pokok utang. Sedangkan untuk komponen belanja tidak langsung terdiri dari ; belanja pegawai, belanja bunga, belanja hibah, belanja bantuan social, belanja bagi hasil kepada pemerintah desa danbelanjatidak terduga. Selanjutnya untuk melihat bagaimana perkembangan ekonomi di Kabupaten Lombok Barat, maka akan dapat ditunjukkan melalui perkembangan PDRB secara time series terhitung sejak Tahun 2014-2018. Namun jika kita ingin melihat lebih rinci lagi bagaimana perkembangan ekonomi Kabupaten Lombok Barat, dapat menggunakan perkembanagn PDRB per kapita. Ini biasa digunakan sebagai salah satu indikator untuk mengetahui tingkat kesejahtraan ekonomi masyarakat secara makro, PDRB per kapita yang tinggi mencerminkan keadaan ekonomi masyarakat yang lebih baik, dan sebaliknya PDRB per kapita yang rendah mencerminkan keadaan ekonomi masyarakat yang kurang berkembang. PDRB per kapita merupakan gambaran dari rata-rata pendapatan yang diterima oleh setiap penduduk pertengahan tahun pada tahun yang sama dapat diperoleh PDRB per kapita untuk tahun yang bersangkutan.

\section{Pertumbuhan PDRB Lombok Barat}

Untuk mengetahui adanya pertumbuhan tingkat kesejahtraan masyarakat, dapat dihitung dengan menggunakan PDRB per kapita atas dasar harga konstan maupun atas dasar harga berlaku. Jika tingkat kesejahtraan masyarakat cukup tinggi, maka ini mengindikasikan adanya pertumbuhan penduduk yang relatif lebih rendah jikadibandingkan dengan laju pertumbuhan PDRB itu sendiri, baik atas dasar harga berlaku maupun atas dasar harga konstan. Untuk mengetahui lebih 
komprehensif tentang laju pertumbuhan

ekonomi Kabupaten Lombok Barat, maka dapat dilihat dari laju pertumbuhan PDRB setiap tahunnya terhitung sejak Tahun 2014-2018 seperti tabel di bawah ini.

Tabel 5. Laju Pertumbuhan PDRB Per Kapita Kabupaten Lombok Barat Atas Dasar Harga Berlaku dan Konstan Tahun 2000 Tahun 2016-2019 (jutaan rupiah).

\begin{tabular}{|c|c|c|c|c|c|c|}
\hline No & S e k t o r & 2014 & 2015 & 2016 & 2017 & 2018 \\
\hline 1 & Atas Dasar Harga Berlaku & $10.131,2$ & $11.446,9$ & $12.668,2$ & $13.955,4$ & $14.480,3$ \\
\hline & Indeks Perkembangan & 144,50 & 163,26 & 180,68 & 190,75 & 200,04 \\
\hline & Laju Pertumbuhan (\%) & 12,73 & 12,99 & 10,67 & 11,00 & 14,00 \\
\hline 2 & Atas Dasar Harga Konstan & $8.708,3$ & $9.264,9$ & $9.795,8$ & $10.432,2$ & $10.491,9$ \\
\hline & Indeks Perkembangan & 116,34 & 123,26 & 129,32 & 132,11 & 135,23 \\
\hline & Laju Pertumbuhan (\%) & 5,70 & 6,38 & 5,73 & 6,54 & 6,73 \\
\hline
\end{tabular}

Sumber : BPS Kabupaten Lombok Barat Tahun 2016-2019

0,81 persen. Seiiring dengan

Memperhatikan table 5. terlihat bahwa selama 4 (empat) tahun Indeks pertumbuhan PDRB Kabupaten Lombok Barat baik atas dasar harga berlaku maupun atas dasar harga konstan berada di atas laju pertumbuhan PDRB Lombok Barat.Sebagai ilustrasi laju pertumbuhan PDRB Kabupaten Lombok Barat tahun 2015 atas dasar harga berlaku meningkat tipis dari tahun 2014 yaitu sebesar 12,73 menjadi 12,99 persen. Sementara untuk tahun 2016 mengalami penurunan menjadi 10,67 dari tahun 2015. Namun pada tahun 2017 dan tahun 2018 mengalami peningkatan dari 11,00 persen menjadi 14,00 persen. Jika dilihat pertumbuhan PDRB atas dasar harga Konstan Nampak terus mengalami peningkatan mulai dari tahun 2014 sampai dengan tahun 2018 kecuali pada tahun 2016 terjadi penurunan sebesar pertumbuhan PDRB tersebut peningkatan PDRB per kapita atas dasar harga berlaku sebesar 12,73 persen di tahun 2014 persen meningkat menjadi 12,99 persen di tahun 2015.Sedangkan untuk tahun 2016, 2017 dan tahun 2018 terjadi juga peningkatan dari 5,73 persen, menjadi 6,54 persen dan 6,73 persen untuk tahun 2018. Peningkatan tersebut sangat membawa arti bagi tingkat kesejahtraan ekonomi masyarakat Kabupaten Lombok Barat. Kondisi ini juga didukung oleh pertumbuhan PDRB atas harga konstan dari 5,70 persen di tahun 2014 menjadi 6,38 persen di tahun 2015. PDRB per kapita adalah merupakan indikator tentang tingkat kesejahtraan masyarakat. Kenaikan-kenaikan yang terjadi secara otomatis telah mampu menurunkan proporsi penduduk miskin di Kabupaten Lombok Barat. 


\section{Kontribusi Belanja Daerah Terhadap PDRB Lombok Barat}

Secara time series terhitung sejak tahun 2014-2018 baik belanja daerah maupun pertumbuhan PDRB mengalami pertumbuhan namun bersifat fluktuatif. Untuk menunjukkan fluktuasi $\begin{array}{lcr}\text { pertumbuhan } & \text { belanja } & \text { daerah } \\ \text { sumbangannya } & \text { terhadap } & \text { laju }\end{array}$ pertumbuhan ekonomi atau PDRB kabupaten Lombok Barat, baik dilihat dari segi harga berlaku maupun dari segi harga konstan tahun 2010, maka dapat disajikan dalam tabel di bawah ini.

Tabel 6. Kontribusi Belanja Daerah Berdasarkan Harga Berlaku Terhadap Laju

Pertumbuhan Ekonomi Lombok Barat Tahun 2016-2019.

\begin{tabular}{|c|c|c|c|}
\hline Tahun & Belanja Daerah & P D R B & Persentase \\
\hline & & Harga Betrlaku & \\
\hline 2014 & $1.115 .213 .561 .837,76$ & 10.131 .268 .500 & 9,08 \\
\hline 2015 & $1.390 .491 .598 .626,42$ & 11.447 .645 .400 & 8,23 \\
\hline 2016 & $1.484 .537 .233 .745,94$ & 12.633 .108 .400 & 8,51 \\
\hline 2017 & $1.668 .418 .316 .826,90$ & 13.955 .402 .000 & 8,36 \\
\hline 2018 & $1.730 .565 .286 .739,00$ & 14.480 .329 .700 & 8,37 \\
\hline Jumlah & $7.389 .225 .994 .561,00$ & 62.647 .754 .000 & 42,55 \\
\hline Rerata & $1.477 .845 .198,805,00$ & 12.529 .550 .800 & 8,51 \\
\hline
\end{tabular}

Sumber : Kabupaten Lombok Barat Tahun 2016-2019

Berdasakan data tabel 6. di atas menggambarkan bahwa persentasi kontribusi belanja daerah terhadap Product Domestic Regional Brutto (PDRB) ditinjau dari segi harga berlaku selama 5 (lima) tahun terakhir terhitung sejak tahun 2014-2018 menunjukkan persentasi yang relatif stagnan, bahkan terjadi peningkatan secara cukup signifikan. Dilihat secara rata-rata persentasi kontribusi belanja daerah terhadap laju pertumbuhan ekonomi Kabupaten Lombok Barat cukup tinggi pada angka rata-rata 8,51 persen. Kondisi ini mengindikasikan bahwa peranan belanja daerah dalam mempercepat laju pertumbuhan ekonomi Kabupaten Lombok Barat ternyata cukup berhasil.

Dikatakan cukup berhasil karena besaran kontribusi belanja daerah terhadap laju pertumbuhan ekonomi daerah Kabupaten Lombok Barat berada di atas rata-rata pertumbuhan ekonomi baik provinsi maupun secara nasional, sehingga sangat beralasan dikatakan cukup berhasil dalam mendorong laju pertumbuhan ekonomi 
daerah. Selanjutnya jika kita ingin melihat bagaimana peranan belanja daerah dan berapa besar persentasi kontribusi belanja daerah terhadap laju pertumbuhan ekonomi Kabupaten Lombok Barat dilihat berdasarkan harga konstan tahun 2010 maka, dapat ditunjukkan pada tabel di bawah ini.

Tabel 7. Kontribusi Belanja Daerah Berdasarkan Harga Konstan 2010 Terhadap Laju Pertumbuhan Ekonomi Lombok Barat Tahun 2016-2019.

\begin{tabular}{|c|c|c|c|}
\hline Tahun & Belanja Daerah & P D R B & Persentase \\
\hline & & Harga Konstan 2010 & \\
\hline 2014 & $1.115 .213 .561 .837,76$ & 8.708 .308 .060 & 7,81 \\
\hline 2015 & $1.390 .491 .598 .626,42$ & 9.264 .354 .700 & 6,66 \\
\hline 2016 & $1.484 .537 .233 .745,94$ & 9.792 .220 .600 & 6,60 \\
\hline 2017 & $1.668 .418 .316 .826,90$ & 10.432 .243 .700 & 6,25 \\
\hline 2018 & $1.730 .565 .286 .739,00$ & 10.491 .887 .800 & 6,06 \\
\hline Jumlah & $7.389 .225 .994 .561,00$ & 48.689 .014 .860 & 33,38 \\
\hline Rerata & $1.477 .845 .198,805,00$ & 9.737 .802 .972 & 6,68 \\
\hline
\end{tabular}

Sumber : Kabupaten Lombok Barat Tahun 2016-2019

mempercepat laju pertumbuhan ekonomi

Berdasakan data tabel 7 di atas menunjukkan bahwa besaran persentasi kontribusi belanja daerah terhadap Product Domestic Regional Brutto (PDRB) dilihat berdasarkan harga konstan tahun 2010 selama 5 (lima) tahun terakhir terhitung sejak tahun 2014-2018 menunjukkan persentasi yang relatif sama dengan kondisi peranan belanja daerah dilihat dari segi harga berlaku bersifat stagnan atau tidak terjadi peningkatan secara signifikan. Namun secara rata-rata persentasi kontribusi belanja daerah terhadap laju pertumbuhan ekonomi dilihat berdasarkan harga berlaku tahun 2010 Kabupaten Lombok Barat relatif cukup tinggi pada angka rata-rata 6,68 persen. Kondisi ini mengindikasikan bahwa peranan belanja daerah dalam
Kabupaten Lombok Barat ternyata cukup berhasil. Dikatakan cukup berhasil karena besaran kontribusi belanja daerah terhadap laju pertumbuhan ekonomi daerah Kabupaten Lombok Barat berada di atas rata-rata pertumbuhan ekonomi baik provinsi maupun secara nasional, sehingga sangat beralasan dikatakan cukup berhasil dalam mendorong laju pertumbuhan ekonomi daerah

\section{KESIMPULAN DAN SARAN}

\section{Kesimpulan}

Berdasarkan hasil perhitungan analisis yang telah dilakukan maka didapatkan kesimpulan dari penelitian ini, ialah:

1. Belanja daerah mulai tahun 2014-2018 berfluktuasi, sebagai contoh tahun 2014 terjadi peningkatan yang sangat signifikan yaitu sebesar 25,00 persen 
dari tahun 2013. Namun pada tahun 2015 terjadi penurunan menjadi 7,00 persen dari Tahun 2014. Namun pada Tahun 2016 terjadi peningkatan lagi secara signifikan menjadi 13,00 persen dari tahun 2015. Tahun 2017 dan 2018 terjadi penurunan lagi secara signifikan menjadi 9,00 persen dan 4,20 persen. Dari segi rata-rata laju pertumbuhan belanja daerah selama 5 (lima) tahun sebesar 11,64 persen tiap tahun.

2. Pertumbuhan PDRB Kabupaten Lombok Barat atas dasar harga berlaku juga mengalami fluktuasi dari tahun 2014 yaitu sebesar 12,73 menjadi 12,99 persen. Sementara untuk tahun 2016 mengalami penurunan menjadi 10,67 dari tahun 2015. Namun pada tahun 2017 dan tahun 2018 mengalami peningkatan dari 11,00 persen menjadi 14,00 persen. Berdasarkan harga Konstan Nampak terus mengalami peningkatan mulai dari tahun 2014 sampai dengan tahun 2018 kecuali pada tahun 2016 terjadi penurunan sebesar 0,81 persen.

3. Kontribusi belanja daerah terhadap Product Domestic Regional Brutto (PDRB) berdasarkan harga konstan tahun 2010 selama 5 (lima) tahun terakhir terhitung sejak tahun 20142018 menunjukkan persentasi yang relatif cukup tinggi dengan angka ratarata 6,68 persen.

4. Kontribusi belanja daerah terhadap Product Domestic Regional Brutto (PDRB) berdasarkan harga berlaku selama 5 (lima) tahun terakhir terhitung sejak tahun 2014-2018 menunjukkan persentasi yang relatif cukup signifikan. Dilihat secara ratarata persentasi kontribusi belanja daerah terhadap laju pertumbuhan ekonomi Kabupaten Lombok Barat rata-rata 8,51 persen.

\section{Saran}

1. Belanja daerah yang terus mengalami peningkatan hendaknya kedepan lebih memperioritaskan pada alokasi belanja yang langsung terkait dengan pelayanan publik seperti bidang pendidikan, kesehatan dan yang mengarah pada kegiatan masyarakat yang bersifat produktif.

2. Pertumbuhan belanja daerah hendaknya mampu menjadi daya dorong pertumbuhan ekonomi masyarakat, sehingga alokasi belanja daerah hendaknya memperioritaskan alokasi anggaran belanjanya ke sektorsektor yang produktif.

3. Mengingat peranan belanja daerah yang sangat strategis dalam mendorong laju pertumbuhan ekonomi 
kabupaten Lombok Barat, maka setiap perencanaan anggaran hendaknya melibatkan berbagai unsur terkait termasuk steakholder agar terjadi tricle down effect terhadap pertumbuhan antar sektor ekonomi di Kabupaten Lombokbarat

\section{DAFTAR PUSTAKA}

2000. "Peraturan Pemerintah Nomor 105 tentang Pengelolaan dan

Pertanggungjawaban Keuangan Daerah". Ditjen PUOD Depdagri, Jakarta.

2001. "Pedoman Umum Penyusunan dan Pelaksanaan APBD Tahun Anggaran 2002". Surat Edaran Mendagri No. 903/2477/SJ,Jakarta.

2003. "Undang-Undang Republik Indonesia Nomor 17 tentang Keuangan Negara". Departemen Keuangan, Jakarta.

2004. "Undang-Undang Nomor 32 tentang Pemerintah Daerah". Penerbit CV. Tamita Utama, Jakarta.

2004. "Undang-Undang Republik Indonesia Nomor 33 tentang Perimbangan Keuangan antara Pemerintah Pusat dan Daerah". Penerbit CV. Tamita Utama, Jakarta.

2005. "Peraturan Pemerintah Nomor 58 tentang Pengelolaan Keuangan Daerah". Ditjen BAKD Depdagri, Jakarta.

2006. Permendagri Nomor : 13 tahun 2006 tentang Pedoman Pengelolaan Keuangan Daerah, Direktorat Jendral Bina Administrasi Keuangan Daerah Depdagri, Jakarta.

2007. Peraturan Pemerintah Nomor : 58 tahun 2007 tentang Pedoman Pengelolaan Keuangan Daerah, Direktorat Jendral Bina Administrasi Keuangan Daerah Depdagri, Jakarta.

Bastian, Indra., 2001. "Manual Akuntansi Keuangan Pemerintah Daerah 2001". Penerbit BPFE, Yogyakarta.

Halim, Abdul., 2002. "Akuntansi Keuangan Daerah". Penerbit Salemba Empat, Jakarta.

2004. "Bunga Rampai Manajemen Keuangan Daerah". Penerbit UPP AMP YKPN, Yogyakarta. 
Hariyadi, Jasagung, 1999, "Evaluasi Sisa Perhitungan Anggaran Pada Perhitungan APBD Kabupaten Belitung Tahun Anggaran 1991/1992 - 2000", Tesis S-2, Program Pasca Sarjana Universitas Gadjah Mada, Yogyakarta (tidak dipublikasikan) Hasbullah Yusuf, 2007, Anaisis Rasio Keuangan Pada Anggaran Pendapatan dan Belanja Daerah (APBD) Kabupaten Lombok Barat Tahun 2002-2005). Penerbit : Mataram Press Majalah IImiah ORIZA Universitas Mataram Vol.VI/No.2 April 2007. 2007, Analisis Kemampuan Keuangan Daerah Kota Mataram. Penerbit : Mataram Press Majalah IImiah ORIZA Universitas Mataram Vol.VI/No.3 Juli 2007. Kama, 2002. "Evaluasi Akuntabilitas Kinerja Perencanaan APBD Tahun 2001 Bidang Pembangunan SDM di Lombok Tengah". Tesis S2, Program Pascasarja Magister Manajemen Fakultas Ekonomi Universitas Mataram (tidak dipublikasikan).

Kuncoro, Mudrajad., 2003. "Metode Riset Untuk Bisnis dan Ekonomi (Bagaimana meneliti \& menulis tesis)". Penerbit Erlangga, Jakarta.

Luo, Huaping and Robert T Golembiewski., 1996. "Budget Deficits in China Calculations, Causes, and Impacts". The Pennsylvania State University, JXR11 @ PSU.EDU.

Mamesah D.J., 1995. "Sistem Administrasi Keuangan Daerah". Penerbit PT. Gramedia Pustaka Utama, Jakarta.

Mardiasmo, MBA, Ak., 2000. Paradigma Baru Pengelolaan Keuangan Daerah Untuk Menyongsong Pelaksanaan Otonomi Daerah, Makalah Seminar HIMMEP, Yogyakarta.

, 2001. "Perencanaan Keuangan Publik Sebagai Suatu Tuntutan Dalam Pelaksanaan Pemerintahan Daerah Yang Bersih dan Berwibawa". Makalah, Jakarta.

2002. "Otonomi dan Manajemen Keuangan Daerah". Serial Otonomi Daerah, Penerbit Andi Offset, Yogyakarta.

2004. "Akuntansi Sektor Publik". Penerbit Andi Offset, Yogyakarta.

Muin Abdul, 2003. Efektivitas dan Efisiensi Pengelolaan Keuangan Daerah Kota Mataram Tahun 1998/1999-2001. Tesis S-2 Program Pascasarjana Magister Manajemen Fakultas Ekonomi Universitas Mataram (tidak dipublikasikan)

Munir Dasril, Djuanda, Tangkilisan., 2004. "Kebijakan dan Manajemen Keuangan Daerah". Penerbit YPAPI, Yogyakarta.

Nazir Moh,Ph.D, 1983. Metode Penelitian, Penerbit : Ghalia Indonesia, Jakarta. 
Suparmoko.M,MA,Ph.D, 2003. Keuangan Negara dalam Teori dan Praktik, Edisi 5, Penerbit BPFE, Yogyakarta

Sugiyono., 1999. "Metode Penelitian Bisnis". Penerbit CV. ALFABETA, Bandung.

Wesen Eugene F. Brigham J. Fred., 2001. "Dasar-dasar Manajemen Keuangan". Edisi Kesembilan Jilid I.

Widodo, Hg, S.T., 1990. "Indikator Ekonomi Dasar Perhitungan Perekonomian Indonesia". Kanisius, Yogyakarta.

William, N Dunn., 1998. "Analisis Kebijakan Publik". Edisi Kedua, Gadjah Mada University Press, Yogyakarta. 